\title{
Flavonoids of Polygonum hydropiper $L$. attenuates lipopolysaccharide-induced inflammatory injury via suppressing phosphorylation in MAPKs pathways
}

Junyu Tao, Yingyi Wei and Tingjun $\mathrm{Hu}^{*}$

\begin{abstract}
Background: Polygonum hydropiper $L$. is widely used as a traditional remedy for the treatment of dysentery, gastroenteritis. It has been used to relieve swelling and pain, dispel wind and remove dampness, eliminate abundant phlegm and inflammatory for a long time. Previous study showed that antioxidants especially flavonoids pretreatment alleviated sepsis-induced injury in vitro and in vivo. In the present study, the possible anti-inflammatory effect of flavonoids from normal butanol fraction of Polygonum hydropiper L. extract (FNP) against inflammation induced by lipopolysaccharide (LPS) was evaluated in vivo and in vitro.

Methods: The content of total flavonoid of FNP was determined by the aluminum colorimetric method. The content of rutin, quercetin and quercitrin was determined by HPLC method. Mice received FNP orally 3 days before an intra-peritoneal (i.p.) injection of lipopolysaccharide (LPS). Total superoxidase dismutase (T-SOD), total antioxidant capacity (T-AOC), glutathione peroxidase (GSH-PX), glutathione (GSH), myeloperoxidase (MPO) and malondialdehyde (MDA) levels were measured. Tumor necrosis factor-a levels in serum and tissue was measured. mRNA expressions of pro-inflammatory cytokines in lung were assessed by Real-Time PCR. Histopathological changes were evaluated in lung, ileum and colon. We also investigated FNP on reactive oxygen species (ROS), nitric oxide (NO) and pro-inflammatory cytokines (TNF-a, IL-1 $13, \mathrm{IL}-6$ and IL-8) production, inducible nitric oxide synthase (iNOS), Cyclooxygenase-2 (COX-2) protein expression, phosphorylation of MAPKs and AMPK in LPS-stimulated RAW264.7 cells.
\end{abstract}

Results: FNP increased the levels of T-SOD, T-AOC, GSH-PX and GSH, decreased the levels of TNF-a, MPO and MDA, attenuate the histopathological lesion in LPS-stimulated mice. FNP inhibited production of inflammatory cytokines, ROS and NO, protein expressions of iNOS and COX-2, phosphorylation of ERK, JNK and c-JUN in MAPKs, promoted phosphorylation of AMPKa suppressed by LPS.

Conclusion: These results suggested in vivo anti-inflammatory activities of FNP might contributed to its enhancement in antioxidant capacity, its inhibitory effects may be mediated by inhibiting the phosphorylation of JNK, ERK and c-JUN in MAPKs signaling pathways.

Keywords: Flavonoids, Antioxidant activity, Anti-inflammatory, AMPK, MAPKs, Phosphorylation

* Correspondence: tingjunhu@126.com

College of Animal Science and Technology, Guangxi University, Nanning

530005, P.R. China 


\section{Background}

Sepsis, a systemic inflammatory response syndrome induced by infection [1], is the most common cause of death in intensive care units [2-4]. It can be defined as a systemic inflammatory disorder and characterized clinically by fever [5], enteritis [6] and acute pneumonia [7]. Previous studies have established that dysfunction of neutrophils granulocyte [8], microcirculation disorder [9], mitochondria dysfunction [10] and translocation of endotoxin [11] are involved in the sepsis course. To investigate the underlying mechanisms of clinical sepsis shock and develop an effective therapeutic strategies to endotoxin challenge, bacterial LPS, the outer membrane component of gram-negative bacterial cell walls [12], is widely used to induce experimental endotoxemia in laboratory animals. Antioxidants alleviated sepsis-induced organ injury. In septic rats and pigs, treatment with $\mathrm{N}$ acetylcysteine did protect rats and pigs against oxidative stress and improves survival rate [13, 14]. Ferulic acid, a well-established natural antioxidant, increased the GSH levels and SOD and GSH-PX activities, decreased the MDA levels and DNA damage in the sepsis-induced rats [15]. Therefore, agents with antioxidant activity that suppress the production of inflammatory cytokines and inflammatory mediators may have therapeutic effects.

Macrophages are mainly responsible for initiating the immune defense and inflammatory reactions. Previous research indicated that LPS-induced iNOS and COX-2 expression in macrophages are regulated by mitogenactivated protein kinases (MAPKs), including extracellular signal regulated kinase (ERK), c-Jun $\mathrm{N}$ terminal kinase (JNK), and p38 [16]. Among them, JNK MAPKs pathway is crucial for macrophage activation and the production of inflammatory cytokines [17]. A wide variety of flavonoid molecules possess anti-inflammatory activity in LPS-induced macrophage by regulating MAPKs signaling pathway [18-20]. Fenoterol inhibits LPS-induced AMPK activation and IL-1 $\beta$ production, AMPK $\alpha 1$ subunit contributed to LPS-induced release of pro-inflammatory cytokines in THP-1 cells [21]. Therefore, treatments aimed at regulating AMPK and MAPKs may have potential therapeutic advantages for inflammatory diseases.

The folk medicinal plant, Polygonum hydropiper $L$. which is widely used in East Asian countries for centuries, especially in Korea, Japan and China. Flavonoids isolated from methanol extract of Polygonum hydropiper $L$. leaves showed strong antioxidant activity [22, 23]. Quercetin was found as one of the active ingredients in $99 \%$ methanol extracts of this plant to inhibits NO and PGE2 production in LPS-treated macrophages [24]. Considering the antioxidant activity and anti-Inflammatory activity of the Polygonum hydropiper L., it is surprising that no pharmacological study has been performed for investigating the protective effect on LPS-induced sepsis in vivo. We hypothesize that flavonoids of Polygonum hydropiper $L$. might has an anti-inflammatory activity. However, there is no scientific evidence, which validate its use in the literature. Therefore, the aim of the present study is to evaluate whether the flavonoids of normal butanol extract from Polygonum hydropiper L.have actions on the production of inflammatory mediators from macrophage so as to inhibit inflammation and protect mice against LPS-induced sepsis.

\section{Methods \\ Materials and reagents}

LPS (Escherichia coli 055:B5) was purchased from Sigma Chemical Co. (St. Louis, USA). Foetal bovine serum and Dulbecco Modified Eagle Mediumas (DMEM) was purchased from Gibco (New York, USA). 3-(4, 5Dimethylthiazol-2-yl)-2, 5-diphenyltetrazolium bromide (MTT) and Fluorescent probe dichlorofluorescin diacetate (DCFH-DA) for ROS dection were purchased from Applygen (Beijing, PR China). Mouse TNF- $\alpha$, IL-6, IL-8, IL-10 and IL-1 $\beta$ enzyme-linked immuno sorbent assay (ELISA) kits were purchased from Neobioscience (Shenzhen, PR China). RAW264.7 cells were purchased from the Type Culture Collection of Chinese Academy of Sciences (Shanghai, PR China). Assay kits for NO, TSOD, T-AOC, GSH-PX, GSH, lysozyme (LZM), acid phosphatase (ACP), MPO, MDA dection were purchased from the Institute of Nanjing Jiancheng Bioengineering (Nanjing, PR China). RNAiso Plus Kit, PrimeScript ${ }^{\bullet}$ RT reagent Kit (Perfect Real Time) and $S Y^{\oplus}{ }^{\oplus}$ Premix Ex TaqTM II Kit (Perfect Real Time) used in RT-qPCR were purchased from Takara Biotechnology (Dalian, PR China). Cell culture dishes and plates (12 mm polycarbonate membrane, $0.4 \mu \mathrm{m}$ pore size, $1.12 \mathrm{~cm}_{2}$ surface area) were purchased from Corning (New York, USA). iNOS (D6B6S), COX-2 (D5H5), MAPKs Family Antibody Sampler Kit, phospho-MAPKs Family Antibody Sampler Kit, c-JUN (60A8), phospho-c-JUN (Ser 3), AMPK $\alpha$ (D5A2), phospho-AMPK $\alpha$ (40H9), $\beta$-Actin (13E5) and GADPH (14C10) were obtained from Cell Signaling Technology (Beverly, USA).

\section{Herbal extract preparation}

Polygonum hydropiper L. was purchased from Tai Hua pharmaceutical Co. Ltd. The plant material was authenticated by Professor Renbin Huang, School of Pharmacy, Guangxi medical University. The voucher specimen (2010-125) has been deposited at the Herbarium of Faculty of Pharmacy, Guangxi medical University for future reference. The extraction and purification of FNP were carried out as followed. Briefly, the air-dried whole plant (500 g) was ground to a powder and extracted with ultrasonic in a buffered solution(Hac-NaAc pH 4.8,1.5 l) 
added with cellulase and pectinase $(0.25 \% \mathrm{~W} / \mathrm{V}$ respectively) at $50{ }^{\circ} \mathrm{C}$ for $1.5 \mathrm{~h}$. Then the $\mathrm{pH}$ value was adjusted to 9.0 with sodium carbonate solution and the enzyme was inactivated at $85{ }^{\circ} \mathrm{C}$ water bath for $15 \mathrm{~min}$, and then macerated with ethanol for $24 \mathrm{~h}$. The extracts were filtered and residue were extracted by maceration in ethanol. The combined filtrate was evaporated under reduced pressure to obtain a crude extract (yield $52.3 \%$ ) and successively treated with petroleum ether $\left(40-60{ }^{\circ} \mathrm{C}\right)$, chloroform, ethyl acetate and normal butanol. The normal butanol fraction yield was $11.96 \%$. The normal butanol fraction was added into column loading-treated XDA-8 macroreticular resin for adsorption for $24 \mathrm{~h}$, and then washed with water and $20 \%$ ethanol, respectively, to get rid of polar impurities. FNP in the column was eluted with $75 \%$ ethanol, and the eluting solution was dried in vacuum condition until yellow powders were achieved.

\section{Quality control of FNP}

Approximately $100 \mathrm{mg}$ of FNP were transferred to a 10 $\mathrm{mL}$ volumetric flask and diluted with methanol to volume. The test sample was finally filtered through a $0.45 \mu \mathrm{m}$ membrane filter before analysis. The total flavonoids content was determined using a colorimetric method as previously described but with slightly modified [25]. Briefly, 1.0 $\mathrm{mL}$ of $\mathrm{NaNO}_{2}$ solution $\left(5 \%\right.$, w/v), $1.0 \mathrm{~mL}$ of $\mathrm{AlCl}_{3}$ solution $(10 \%)$, and $4.0 \mathrm{~mL} \mathrm{NaOH}$ solution $(1.0 \mathrm{~mol} / \mathrm{L})$ were mixed with the same volume of the test sample. The final volume was adjusted to $25 \mathrm{~mL}$ with methanol $(80 \%$, v/v). The mixture was allowed to stand for $5 \mathrm{~min}$ and the absorbance was measured at $510 \mathrm{~nm}$ against the same mixture, without the sample as a blank. Rutin was used as a reference standard and the total flavonoids content was expressed as rutin. The calibration curve $(\mathrm{Y}=0.0011 \mathrm{X}+$ 0.00125 where $\mathrm{X}$ was absorbance value of sample, and $\mathrm{Y}$ was sample concentration) was ranged from 100 to 500 $\mu \mathrm{g} / \mathrm{mL} \quad\left(\mathrm{R}_{2}=0.9992\right)$. The contents of three markers (rutin, quercetin and quercitrin) in the extract samples were determined by High Performance Liquid Chromatography (HPLC) using followed chromatographic condition: Waters e2695 separation module and Waters 2998 photodiode array detector were controlled by EMPOWER $^{\text {mix }} 2$ chromatography data sofeware (Waters Co. Ltd. USA). Waters X Bridge ${ }^{\text {tu }}$ C18 HPLC column $(4.6 \times$ $250 \mathrm{~mm} 5 \mu \mathrm{m}$, Waters Co. Ltd. USA). Column temperature was kept constantly at $30^{\circ} \mathrm{C}$. UV detection wavelength was $254 \mathrm{~nm}$. The injection volume was $10 \mu \mathrm{L}$. The isocratic mobile phase consisted of acetonitrile- $0.3 \%$ phosphoricacid $(27: 73, \mathrm{v} / \mathrm{v})$ was used to elute for $40 \mathrm{~min}$ and the flow rate was kept at $1.0 \mathrm{~mL} / \mathrm{min}$.

\section{Animals}

The study protocol was approved by the Ethics Committee of Guangxi University and was performed in accordance with the Guiding Principles for the Care and Use of Laboratory Animals. Male special pathogen free KM mice were obtained from the Laboratory Animals Center of Guangxi Medical University (Certificate No. 2011-002). After three days of acclimatization, 50 mice were randomly divided into five groups of 10 mice each. Mice in the LPS alone group were injected intraperitoneally with $17 \mathrm{mg} / \mathrm{kg}$ (body weight) of Escherichia coli LPS (Serotype 055:B5, Sigma) in phosphate-buffered saline (PBS) [26], while control mice were injected with only PBS $(10 \mathrm{~mL} / \mathrm{kg})$. The animals in FNP50, FNP100 and FNP200 group were orally administrated with diverse dose FNP $(50 \mathrm{mg} / \mathrm{kg}, 100 \mathrm{mg} / \mathrm{kg}$ or $200 \mathrm{mg} / \mathrm{kg})$ for 3 days before instillation of LPS. All mice were euthanized at $24 \mathrm{~h}$ after LPS or PBS instillation, and the samples were collected for subsequent analysis.

\section{Mortality and measurement of TNF-a values}

The mortality of mice was recorded for $24 \mathrm{~h}$ after the LPS challenge in each treated group. Homogenates of murine liver and intestine were prepared using physiological saline (1:9, w/v ratio) and kept on an ice bath. The homogenates were then centrifuged at $1,000 \mathrm{~g}$ at $4{ }^{\circ} \mathrm{C}$ for $15 \mathrm{~min}$, and the supernates were collected. Blood samples were collected and the TNF$\alpha$ levels in serum and supernates was analyzed using a cytokine-specific ELISA kit according to the manufacturer's protocol.

\section{Biochemical analysis}

Homogenates of murine small intestine were prepared using physiological saline (1:9, w/v ratio) and kept on an ice bath. The homogenates were then centrifuged at $1,000 \mathrm{~g}$ at $4{ }^{\circ} \mathrm{C}$ for $15 \mathrm{~min}$, and the supernates were collected and analyzed for MPO activities and MDA levels. Homogenates of murine liver were prepared using physiological saline $(1: 9, \mathrm{w} / \mathrm{v})$ and kept on an ice bath. The homogenates were then centrifuged at 1,000 g at $4{ }^{\circ} \mathrm{C}$ for $15 \mathrm{~min}$, and the supernates were collected and analyzed for T-SOD, T-AOC and GSH-PX activities. Blood samples were collected and the serum were then centrifuged at $1,000 \mathrm{~g}$ at $4{ }^{\circ} \mathrm{C}$ for $15 \mathrm{~min}$, and the supernates were collected and analyzed for levels of LZM, ACP and GSH.

Quantification of messenger RNA (mRNA) in lung of mice Total RNA was extracted from lung tissues by using RNAiso Plus Kit, and RNA was reverse transcribed to cDNA using reverse transcription and amplified by PCR with PrimeScript ${ }^{\oplus} \mathrm{RT}$ reagent Kit according to the manufacturer's instructions. Relative expression of TNF$\alpha 、$ IFN- $\alpha$, IFN- $\gamma$ and IL-2 were measured with a SYBER green detection system by using CFX96 RealTime PCR Detection System (Bio-Rad, USA), Each 
reaction was run in triplicate and the cycle threshold (CT) values for each mRNA were subtracted from that of $\beta$-actin mRNA averaged and converted from loglinear to linear term. The primer sequences used were as follows: TNF- $\alpha$ (NM_013693): forward: 5'-AAGACCTC TATGCCAACACAGT-3' and reverse: 5'-TTTACTC AGTGCCAGAAGCTGGA-3'; IL-2 (NM_008366.3): forward: 5'-CCCAGGATGCTCACCTTCA-3' and reverse: 5'CCGCAGAGGTCCAAGTTCA-3'; IFN- $\alpha$ (NM_010502.2): forward: 5'-CTGTGCTTTCCTGATGGTCCTG-3' and reverse: 5'-GGAATCCAAAGTCCTTCCTGTCCT-3'; IFN- $\gamma$ (NM_00801778): forward: 5'-GCTTTGCAG CTCTTCCTCATG-3' and reverse: 5'-CTTCCACAT CTATGCCACTTGAG-3'; $\quad \beta$-actin (NM_007393.3): forward: 5'-AAGACCTCTATGCCAACACAGT-3' and reverse: 5'-TTTACTCAGTGCCAGAAGCTGGA-3'.

\section{Histopathology}

To characterize the histological alterations, the lungs, ileum and colon of the mice were excised and fixed in $10 \%$ neutral buffered formalin. The tissue samples were dehydrated with graded alcohol, embedded in paraffin, and the sections stained with hematoxylin and eosin were examined by light microscopy.

\section{Cell culture and treatments}

Mouse macrophage RAW 264.7 cells were cultured in DMEM supplemented with $10 \%$ heat-inactivated fetal bovine serum, 100 units $/ \mathrm{mL}$ penicillin sodium, $100 \mu \mathrm{g} / \mathrm{mL}$ strepto-mycin and $2 \mathrm{mmol} / \mathrm{L}$ glutamine at $37{ }^{\circ} \mathrm{C}$ under a humidified atmosphere of $5 \% \mathrm{CO}_{2}$. In all experiments, cells were allowed to acclimate for $24 \mathrm{~h}$ before any treatment. Cells were incubated with or without FNP that was added $1 \mathrm{~h}$ prior to LPS treatment.

\section{MTT assay for testing cell viability}

The examination of cytotoxicity induced by FNP was performed by MTT assay [27]. RAW 264.7 cells were mechanically scraped, plated at a density of $2 \times 10^{5}$ cells $/ \mathrm{mL}$ into 96 -well plates and incubated in a $37{ }^{\circ} \mathrm{C}, 5 \%$ $\mathrm{CO}_{2}$ incubator overnight. FNP was dissolved in Dimethyl Sulphoxide (DMSO), and the DMSO concentrations in all assays was not exceed $0.1 \%$. After overnight incubation, the cells were treated with diverse concentrations of FNP $(20-400 \mu \mathrm{g} / \mathrm{mL})$ in the presence or absence of LPS $(1 \mu \mathrm{g} / \mathrm{mL})$ according to the experimental design. After $20 \mathrm{~h}, 20 \mu \mathrm{L}$ of $5 \mathrm{mg} / \mathrm{mL}$ MTT was added to each well and the cells were further incubated for an additional $4 \mathrm{~h}$. MTT was removed and cells were lysed with $150 \mu \mathrm{L} /$ well DMSO. The optical density was measured at $570 \mathrm{~nm}$ on a microplate reader.

\section{Measurement of NO production}

After pre-incubation of RAW264.7 cells $\left(1 \times 10^{6}\right.$ cells/ $\mathrm{mL})$ for $18 \mathrm{~h}$, cells were pre-treated with FNP (20-80 $\mu \mathrm{g} / \mathrm{mL}$ ) for $1 \mathrm{~h}$ and were further incubated with LPS (1 $\mu \mathrm{g} / \mathrm{mL}$ ) for $12 \mathrm{~h}$ or $24 \mathrm{~h}$. The inhibitory effect of FNP on NO production was determined by Griess reagent as described previously [28].

\section{Measurement of ROS levels}

After pre-incubation of RAW264.7 cells $\left(1 \times 10^{6}\right.$ cells $/ \mathrm{mL}$ ) for $18 \mathrm{~h}$, the cells were pre-treated with FNP $(20,40$ or $80 \mu \mathrm{g} / \mathrm{mL})$ for $1 \mathrm{~h}$ and were further incubated with LPS $(1 \mu \mathrm{g} / \mathrm{mL})$ for $12 \mathrm{~h}$ or $24 \mathrm{~h}$. The inhibitory effect of FNP on ROS production was determined by fluorescent probe DCFH-DA as described previously [29].

\section{Measurement of inflammatory cytokine values}

To investigate the effect of FNP on inflammatory cytokine levels from LPS-treated RAW 264.7 cells, The preincubated cells $\left(1 \times 10^{6}\right.$ cells $\left./ \mathrm{mL}\right)$ were pretreated with 20, 40 or $80 \mu \mathrm{g} / \mathrm{mL}$ of FNP for $1 \mathrm{~h}$ prior to $1 \mathrm{~h}$ treatment with $1 \mu \mathrm{g} / \mathrm{mL}$ LPS at $37{ }^{\circ} \mathrm{C}, 5 \% \mathrm{CO}_{2}$ incubator. $24 \mathrm{~h}$ later post LPS treatment, cell-free supernatants were collected and stored at $-20{ }^{\circ} \mathrm{C}$ until assayed for cytokine levels. The concentrations of TNF- $\alpha$, IL-6, IL-8, IL-10 and IL-1 $\beta$ in the supernatants of RAW 264.7 cell culture were determined by a cytokine-specific ELISA kit, according to the manufacturer's instructions.

\section{Western blot analysis}

RAW 264.7 cells $\left(2 \times 10^{5}\right.$ cells $\left./ \mathrm{mL}\right)$ were plated in 24 well plates and pretreated with $20 \mu \mathrm{g} / \mathrm{mL}$ or $80 \mu \mathrm{g} / \mathrm{mL}$ of FNP for $2 \mathrm{~h}$ or $4 \mathrm{~h}$ and then stimulated with $1 \mu \mathrm{g} / \mathrm{mL}$ of LPS for $1 \mathrm{~h}$. After incubation, the cells were collected and washed twice with cold PBS. The washed cell pellets were resuspended in extraction lysis buffer (1:10 $10 \times$ RIPA Buffer(CST,USA),1:10 cOmplete ULTRA EDTAfree protease inhibitor cocktail tablets (Roche, Swiss), 1:10 PhosSTOP Phosphatase Inhibitor Cocktail Tablets (Roche, Swiss)) and maintained on ice for $30 \mathrm{~min}$. The lysates were centrifuged $\left(12,000 \mathrm{~g}\right.$ at $\left.4{ }^{\circ} \mathrm{C}\right)$ for $5 \mathrm{~min}$ to obtain the cytosolic fraction and the protein concentrations were determined using a $\mathrm{BCA}^{\mathrm{m}}$ protein assay kit (Cwbiotech, China) according to the manufacturer's instructions. Aliquots of the cell extracts (50 $\mu \mathrm{g}$ of protein) were separated on $10 \%$ SDS-polyacrylamide gel and transferred onto a polyvinylidene fluoride (PVDF) membrane (Roche, Swiss) with a glycine transfer buffer [192 mM glycine, $25 \mathrm{mM}$ Tris- $\mathrm{HCl}(\mathrm{pH}$ 8.8), $10 \%$ methanol (v/v)]. The membrane was incubated overnight with specific primary antibody(CST,USA) at $4{ }^{\circ} \mathrm{C}$ after blocking the nonspecific site with $5 \%$ bovine serum albumin (BSA). The membrane were washed with Tween 
20/Tris buffered saline [TTBS, $20 \mathrm{mM}$ Tris- $\mathrm{HCl}$ buffer, $\mathrm{pH}$ 7.6, containing $137 \mathrm{mM} \mathrm{NaCl}$ and $0.05 \%(\mathrm{v} / \mathrm{v})$ Tween 20] and incubated an additional $60 \mathrm{~min}$ with a peroxidase-conjugated secondary anti-mouse antibody(1:5000 CST,USA) at room temperature. The membranes were washed with TTBS twice and the immunoactive proteins were detected using an enhanced chemiluminescence (ECL) Western blotting detection kit (Merck Millipore, Germany).

\section{Statistical analysis}

All experimental data in this study was represented as mean \pm SD. All statistical comparisons were conducted using oneway ANOVA followed by Tukey's test and analyzed using SPSS 16.0 for Windows. Difference was considered statistically significant when $P<0.05$, whereas less than 0.01 were considered extremely significant $(P<0.01)$.

\section{Results}

\section{Quality evaluation of FNP}

The content of total flavonoids in the extract was determined quantitatively as $55.3 \%$ by colorimetric method by using rutin as the standard. The contents of rutin, quercetin and quercitrin in the extract detected by HPLC analysis (Fig. 1) is $21.9 \%, 8.2 \%$ and $20.6 \%$, respectively.

FNP reduced mortality and pathological damages in LPSstimulated mice

First, we examined the effect of FNP (50, 100 or 200 $\mathrm{mg} / \mathrm{kg}$ oral administration) on LPS $(17 \mathrm{mg} / \mathrm{kg}$, intraperitoneally) induced mortality for $24 \mathrm{~h}$ in mice. No mice were dead in control group while LPS treated alone caused $30 \%$ mortality within $24 \mathrm{~h}$. Pretreated with FNP significantly reduced LPS induced death. No mice were dead while pretreated with FNP. As shown in Fig. 2, no obvious histopathological change was found in lung

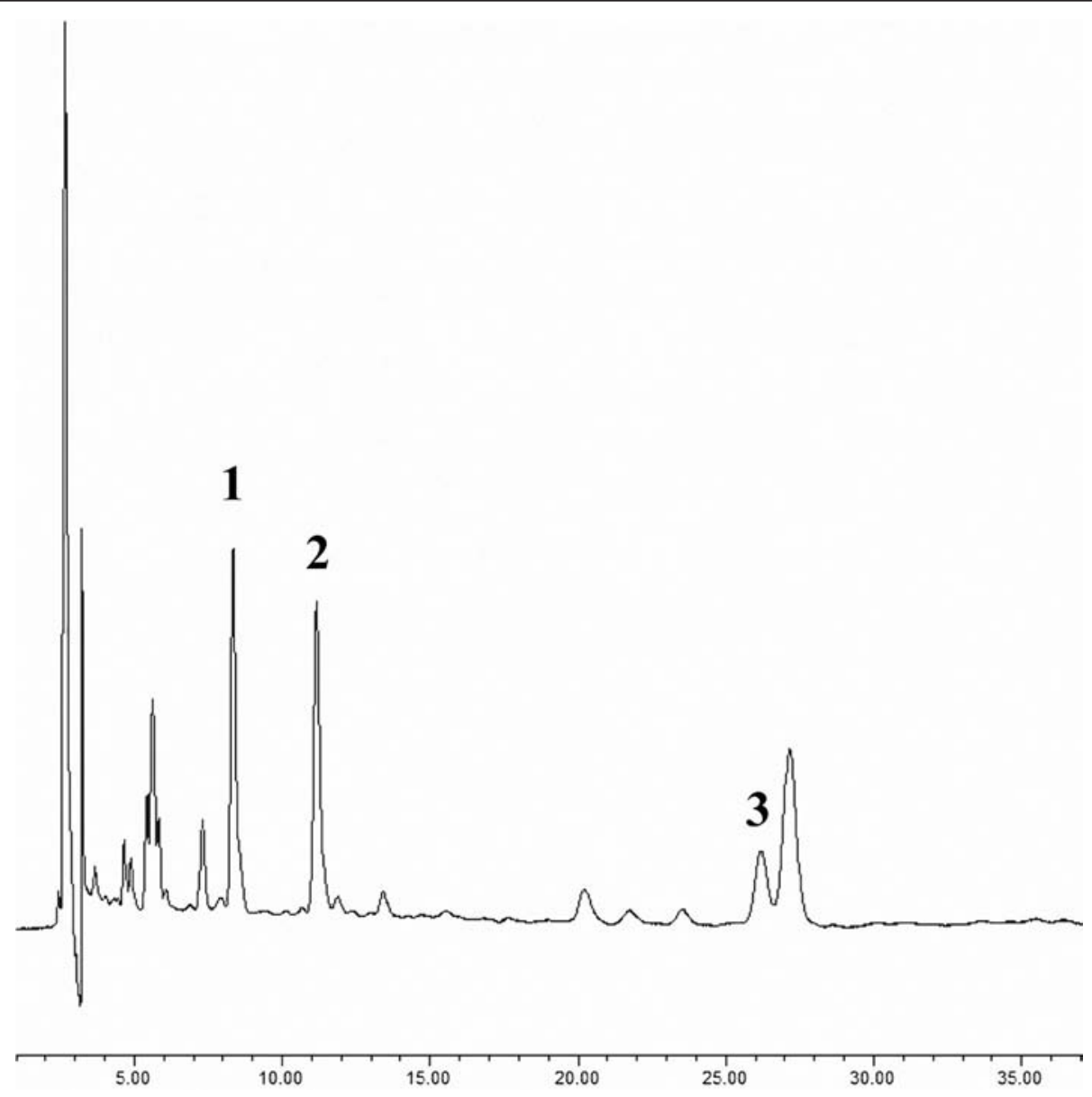

Fig. $1 \mathrm{HPLC}$ analysis of FNP. Notes: The isolated compounds were identified in the extract by comparing their retention times. The chromatograms were obtained at a wavelength of $254 \mathrm{~nm}$. (1) rutin (2) quercitrin (3) quercetin 

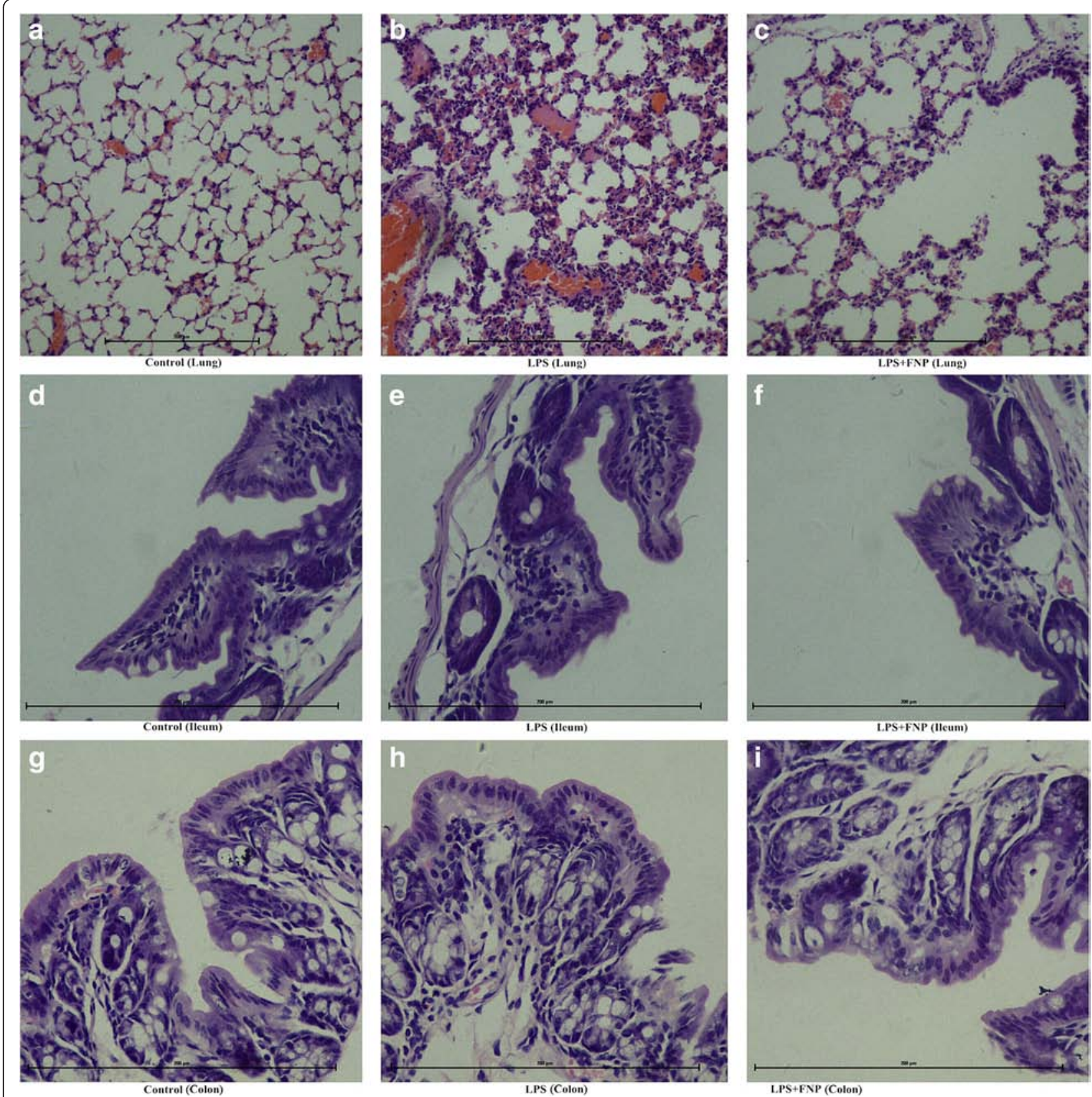

Fig. 2 Protective effect of FNP on lung, ileum and colon in LPS-stimulated mice. Notes: The mice in the LPS group were injected intraperitoneally with $17 \mathrm{mg} / \mathrm{kg}$ (body weight) of LPS, while control group were injected with PBS (10 mL/kg). FNP50, FNP100 and FNP200 group were orally administrated with diverse dose FNP (50 mg/kg, $100 \mathrm{mg} / \mathrm{kg}$ and $200 \mathrm{mg} / \mathrm{kg}$ ) for 3 days before instillation of LPS. Histopathological studies by light microscope showing morphologically normal lung, ileum and colon tissues from mice in the control group (a, $\mathbf{d}$ and $\mathbf{g}$ ). Incrassation of alveolar wall, serous exudation, hemorrhage and infiltration of PMN in lung from LPS-treated group (b) and no serous exudation or hemorrhage and less incrassation of alveolar wall and infiltration by PMN in lung from LPS-treated mice treated with FNP (c). Necrosis of epithelial cell, disorder of epithelial cell arrangement and fall of epithelium of intestinal villus in ileum and colon from LPS-treated group (e and $\mathbf{h}$ ) and less necrosis of epithelial cell in ileum and colon from LPS-treated mice treated with FNP (f and $\mathbf{i})$. Tissue sections were stained with hematoxylin and eosin and view by light microscopy (200 and 400x)

from control group (Fig. 2a). Remarkable incrassation of alveolar wall, serous exudation, hemorrhage and infiltration of polymorphonuclear neutrophil (PMN) was presented in LPS-treated group (Fig. 2b). No serous exudation and hemorrhage, less incrassation of alveolar wall and less infiltration by PMN was shown in FNP pretreated groups (Fig. 2c) as compared with LPStreated group. No obvious histopathological change was 
found in ileum from control group (Fig. 2d). Necrosis of epithelial cell, disorder of epithelial cell arrangement and fall of epithelium of intestinal villus was presented in LPS-treated group (Fig. 2e). Less epithelial cell necrosis and less fall of epithelium of intestinal villus was shown in FNP pretreated groups (Fig. 2f) as compared with LPS-treated group. No obvious histopathological change was found in colon from control group (Fig. 2g). Indistinct villus border, necrosis of epithelial cell, disorder of epithelial cell arrangement and fall of epithelium of intestinal villus was presented in LPS-treated group (Fig. 2h). Less epithelial cell necrosis and less fall of epithelium of intestinal villus was shown in FNP pretreated groups (Fig. 2i) as compared with LPS-treated group.

\section{FNP reduced TNF-a levels in blood and tissues in LPS- stimulated mice}

As shown in Fig. 3a, mice with LPS treated alone resulted in significant increases in TNF- $\alpha$ production in serum, liver and intestine homogenates as compared to the control group. The production of TNF- $\alpha$ was $29.9 \pm$ $4.8,36.9 \pm 3.7,47.5 \pm 3.6 \mathrm{ng} / \mathrm{L}$ respectively. However, the production of TNF- $\alpha$ in serum, liver and intestine
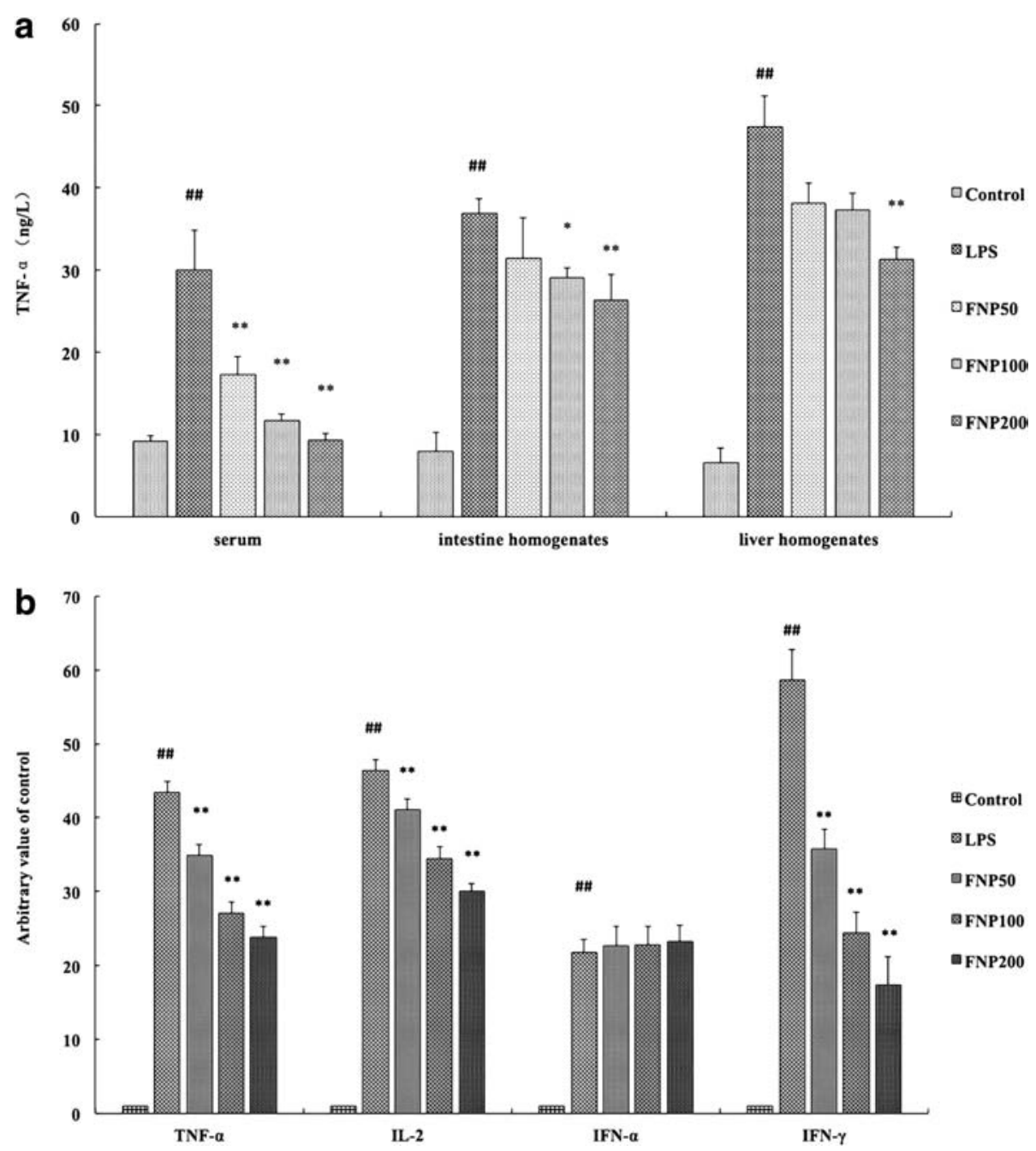

Fig. 3 Effects of FNP pretreatment on TNF-a levels in blood and tissues, mRNA expression in lung. Notes: The mice in the LPS group were injected intraperitoneally with $17 \mathrm{mg} / \mathrm{kg}$ (body weight) of LPS, while control group were injected with PBS (10 mL/kg). FNP50, FNP100 and FNP200 group were orally administrated with diverse dose FNP $(50 \mathrm{mg} / \mathrm{kg}, 100 \mathrm{mg} / \mathrm{kg}$ and $200 \mathrm{mg} / \mathrm{kg}$ ) for 3 days before instillation of LPS. Serum and lung were collected, liver and intestine homogenates were prepared. TNF-a levels of serum and homogenates were shown in (a). The level of mRNA expression in lung is expressed as fold-change relative to the control group (b). The mRNA expression of TNF-a, IFN-a, IFN- $y$ and IL-2 was analyzed by qRT-PCR. Data are presented as the means \pm SD from three independent experiments $(n=10)$. \# $P<0.01$ vs control group; ${ }_{*} P<0.05$ vs LPS group; $* P<0.01$ vs LPS group 
homogenates was significantly inhibited as pretreated with FNP as compared with LPS-treated group. FNP pretreatment $(200 \mathrm{mg} / \mathrm{kg})$ reduced this TNF- $\alpha$ level by $68.7 \%, 28.5 \%$ and $34.1 \%$ respectively. These results show FNP reduced TNF- $\alpha$ levels on LPS-stimulated mice.

\section{FNP down regulated mRNA expression in lung in LPS- stimulated mice}

The effects of FNP on TNF- $\alpha$, IFN- $\alpha$, IFN- $-\gamma$, IL- 2 and IL-10 mRNA expressions were detected by qRT-PCR. As shown in Fig. 3b, mice with LPS treated alone resulted in significant increases in TNF- $\alpha(43.4 \pm 1.5)$, IFN- $\alpha$ $(21.8 \pm 1.8), \quad$ IFN $-\gamma(58.6 \pm 4.2)$ and IL-2 $(46.4 \pm 1.5)$ mRNA expression levels in lung as compared to the control group. However, pretreated with FNP (50, 100 or $200 \mathrm{mg} / \mathrm{kg}$ ) significantly decreased mRNA expression level of TNF- $\alpha$, IFN- $\gamma$ and IL- 2 as compared to the LPStreated group. FNP did not inhibited mRNA expressions of IFN- $\alpha$ induced by LPS.

\section{FNP increased antioxidant capacity in LPS-stimulated mice}

As shown in Fig. 4a and 4b, mice with LPS treated alone resulted in significant increases in MDA $(9.6 \pm 1.5 \mathrm{nmol} /$ mgprot) and MPO $(1.6 \pm 0.2 \mathrm{U} / \mathrm{g})$ production in small intestine homogenates as compared to the control group. The MDA and MPO level was increased by 247.6 $\%$ and $216.1 \%$ as compared to the control group respectively. However, the production of MDA in small intestine homogenates was significantly inhibited as pretreated with FNP (50, 100 and $200 \mathrm{mg} / \mathrm{kg}$ ) as compared with LPS-treated group, the MDA level was decreased by $29.6 \%, 36.1 \%$ and $45.1 \%$ respectively. Pretreated with FNP (50, 100 and $200 \mathrm{mg} / \mathrm{kg}$ ) significantly inhibited the increase of MPO in small intestine homogenates as compared with LPS-treated group, the MPO level was decreased by $19.6 \%, 62.5 \%$ and $63.7 \%$ respectively.

As shown in Fig. 4c, no significant difference but a decrease was shown in T-AOC level between LPStreated group and control group. However, the level of T-AOC in liver homogenates was significantly promoted as pretreated with FNP at the dose of $200 \mathrm{mg}$ / $\mathrm{kg}$ as compared with LPS-treated group, the T-AOC level was increased by $36.1 \%$. As shown in Fig. 4d, mice with LPS treatment alone resulted in significant decreases in T-SOD $(107.3 \pm 24.7 \mathrm{U} / \mathrm{mgprot})$ activity in liver homogenates as compared to the control group, the T-SOD level was decreased by $26.2 \%$. However, pretreated with FNP (100 and $200 \mathrm{mg} / \mathrm{kg}$ ) significant increases T-SOD activities as compared to the LPS-treated group, the T-SOD level was increased by $54.6 \%$ and $87.2 \%$ respectively. As shown in
Fig. 4e, mice with LPS treatment alone resulted in significant decreases in GSH-PX (379.7 $\pm 64.8 \mathrm{U} /$ mgprot) activities in liver homogenates as compared to the control group, the GSH-PX level was decreased by $34.2 \%$. However, pretreated with FNP (50, 100 and $200 \mathrm{mg} / \mathrm{kg}$ ) significant increases GSH-PX level as compared to the LPS-treated group, the GSH-PX level was increased by $80.3 \%, 117.5 \%$ and $140.3 \%$ respectively.

As shown in Fig. 4f, no significant difference but a decrease was shown in GSH level between LPS group and control group. However, the level of GSH in serum was significantly promoted as pretreated with FNP (50, 100 and $200 \mathrm{mg} / \mathrm{kg}$ ) as compared with LPS-treated group, the GSH level was increased by $29.2 \%, 59.3 \%$ and 168.0 $\%$ respectively. As shown in Fig. 4g, mice with LPS treatment alone resulted in significant increases in ACP $(119.5 \pm 19.3 \mathrm{king}$ unit/100 $\mathrm{mL})$ level in serum as compared to the control group, the ACP level was increased by $70.9 \%$. However, pretreated with FNP (100 and 200 $\mathrm{mg} / \mathrm{kg}$ ) significantly decreased ACP level as compared to the LPS-treated group, the ACP level was decreased by $27.4 \%$ and $29.3 \%$ respectively. As shown in Fig. 4h, no significant difference but a decrease was shown in LZM level between LPS group and control group. However, pretreated with FNP (50, 100 and $200 \mathrm{mg} / \mathrm{kg}$ ) significantly increased LZM level as compared to the LPStreated group, the LZM level was increased by $71.0 \%$, $172.5 \%$ and $195.4 \%$ respectively.

\section{Effects of FNP on RAW 264.7 macrophage viability}

To assess the suitable concentration of FNP for the experiment, RAW 264.7 cells were incubated with FNP at concentrations ranging from 20 to $400 \mu \mathrm{g} / \mathrm{mL}$ and cell viability was measured by MTT test $24 \mathrm{~h}$ later. FNP at concentrations from 20 to $300 \mu \mathrm{g} / \mathrm{mL}$ had no cytotoxic effect on RAW 264.7 cells. An extremely higher cell viability was observed in the cells treated with FNP at concentration $20 \mu \mathrm{g} / \mathrm{ml}$ compared to the control group $(P<0.01)$ (Fig. 5a), therefore, we chose 40 and $80 \mu \mathrm{g} / \mathrm{mL}$ to investigate intervention effects of FNP in our further experiment.

\section{FNP reduced NO and ROS production in LPS-stimulated RAW 264.7 macrophages}

Nitrite concentration in the medium was determined by using Griess reagent. ROS production was determined by fluorescent probe DCFH-DA. RAW 264.7 cells with LPS treated alone resulted in extremely significant increases in NO production as compared to the control group. The NO level was increased by $87.4 \%$ as compared to control group. However, pretreated with FNP (80, 40 and $20 \mu \mathrm{g} / \mathrm{mL}$ ) significantly inhibited the production of $\mathrm{NO}$ in $24 \mathrm{~h}$ after LPS 

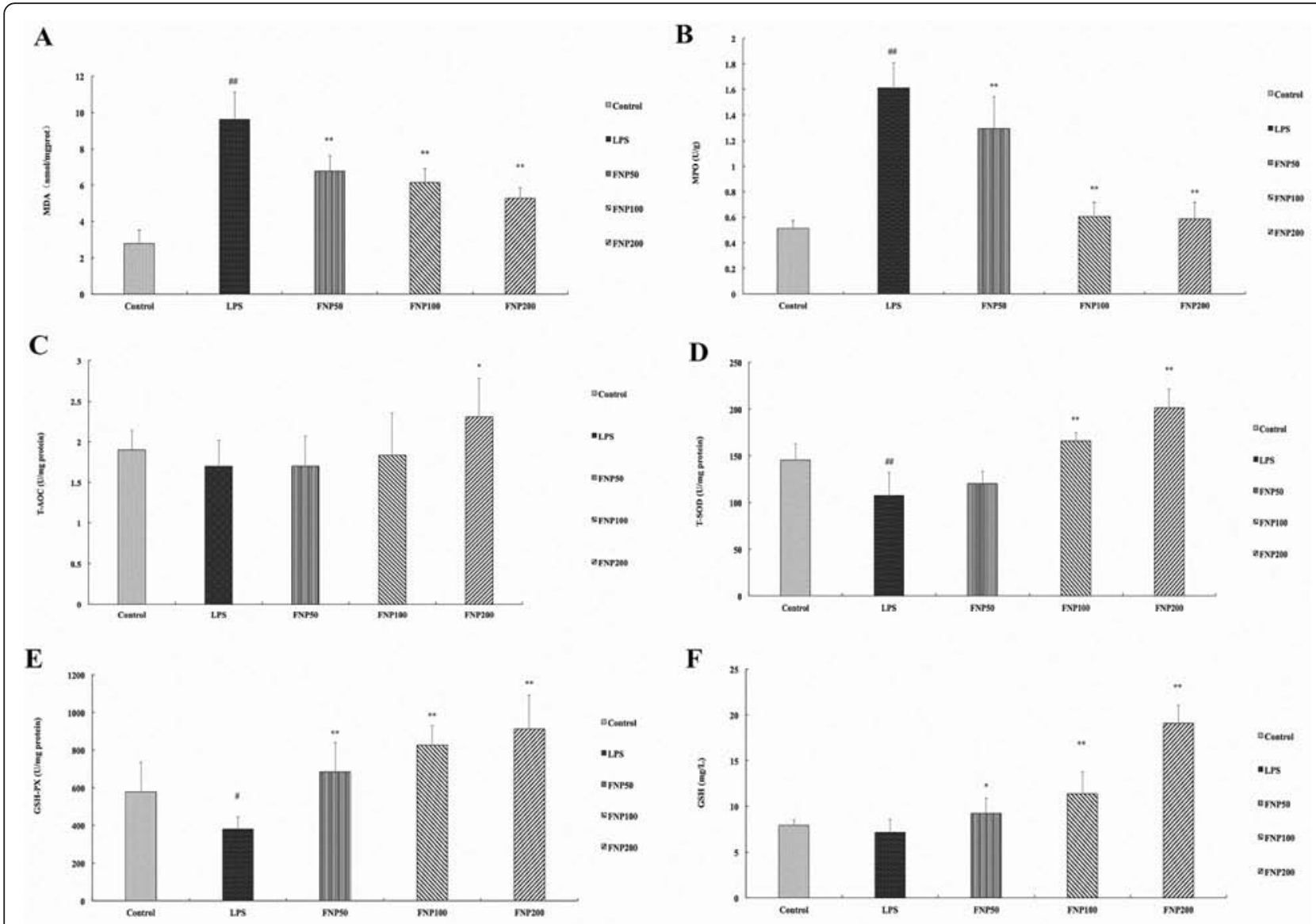

G

H
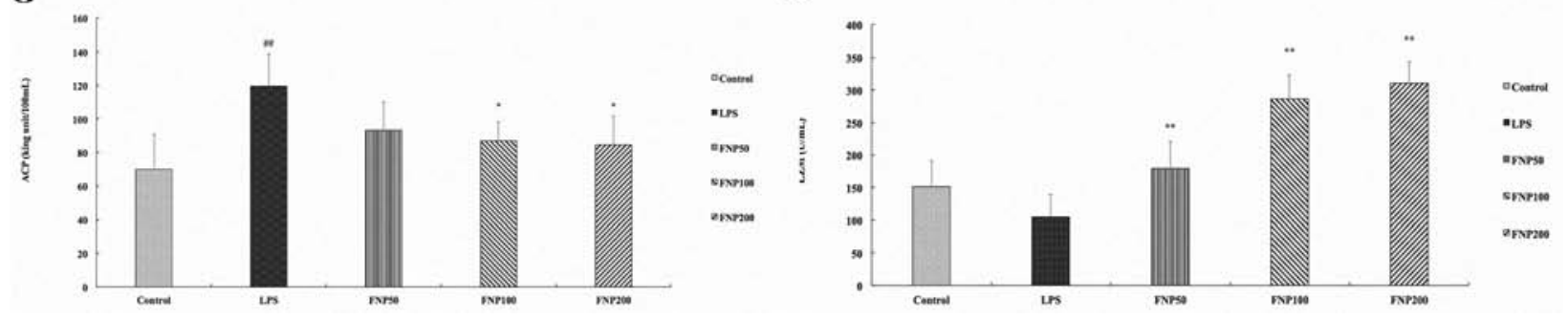

Fig. 4 Effects of FNP on antioxidant capacity in LPS-stimulated mice. Notes: The mice in the LPS group were injected intraperitoneally with 17 $\mathrm{mg} / \mathrm{kg}$ (body weight) of LPS, while control group were injected with PBS (10 mL/kg). FNP50, FNP100 and FNP200 group were orally administrated with diverse dose FNP (50 mg/kg, $100 \mathrm{mg} / \mathrm{kg}$ and $200 \mathrm{mg} / \mathrm{kg}$ ) for 3 days before instillation of LPS. Serum, homogenates of small intestine and liver were prepared. (a) MDA level in small intestine. (b) MPO level in small intestine. (c) T-AOC level in liver. (d) T-SOD level in liver. (e) GSH-PX level in liver. (f) GSH level in serum. (g) ACP level in serum. (h) LZM level in serum. Each column represented as the means \pm SD from three independent experiments $(n=10)$.\#\# $P<0.01$ vs control group; $* P<0.05$ vs LPS group; $* * P<0.01$ vs LPS group

stimulated (Fig. 5b). The NO level was decreased by $46.5 \%, 46.9 \%$ and $46.9 \%$ respectively. RAW 264.7 cells with LPS treated alone resulted in significant increases in ROS production as compared to the control group. The ROS level was increased by $38.5 \%$ as compared to control group. However, the production of ROS was significantly inhibited as pretreated with FNP $(80,40$ or $20 \mu \mathrm{g} / \mathrm{mL}) 12 \mathrm{~h}$ and $24 \mathrm{~h}$ after LPS stimulated (Fig. 5c).
FNP reduced inflammatory cytokine production in LPSstimulated RAW 264.7 macrophages

Inflammatory cytokine level were determined by cytokine-specific ELISA kit. RAW 264.7 cells with LPS treated alone resulted in significant increases in cytokine production (TNF- $\alpha$, IL-1 $\beta$, IL-6, IL- 8 and IL10) as compared to the control group (Fig. 6a and $6 \mathrm{~b})$. However, the production of IL-6 was significantly inhibited as pretreated with FNP (80, 40 and $20 \mu \mathrm{g} /$ 

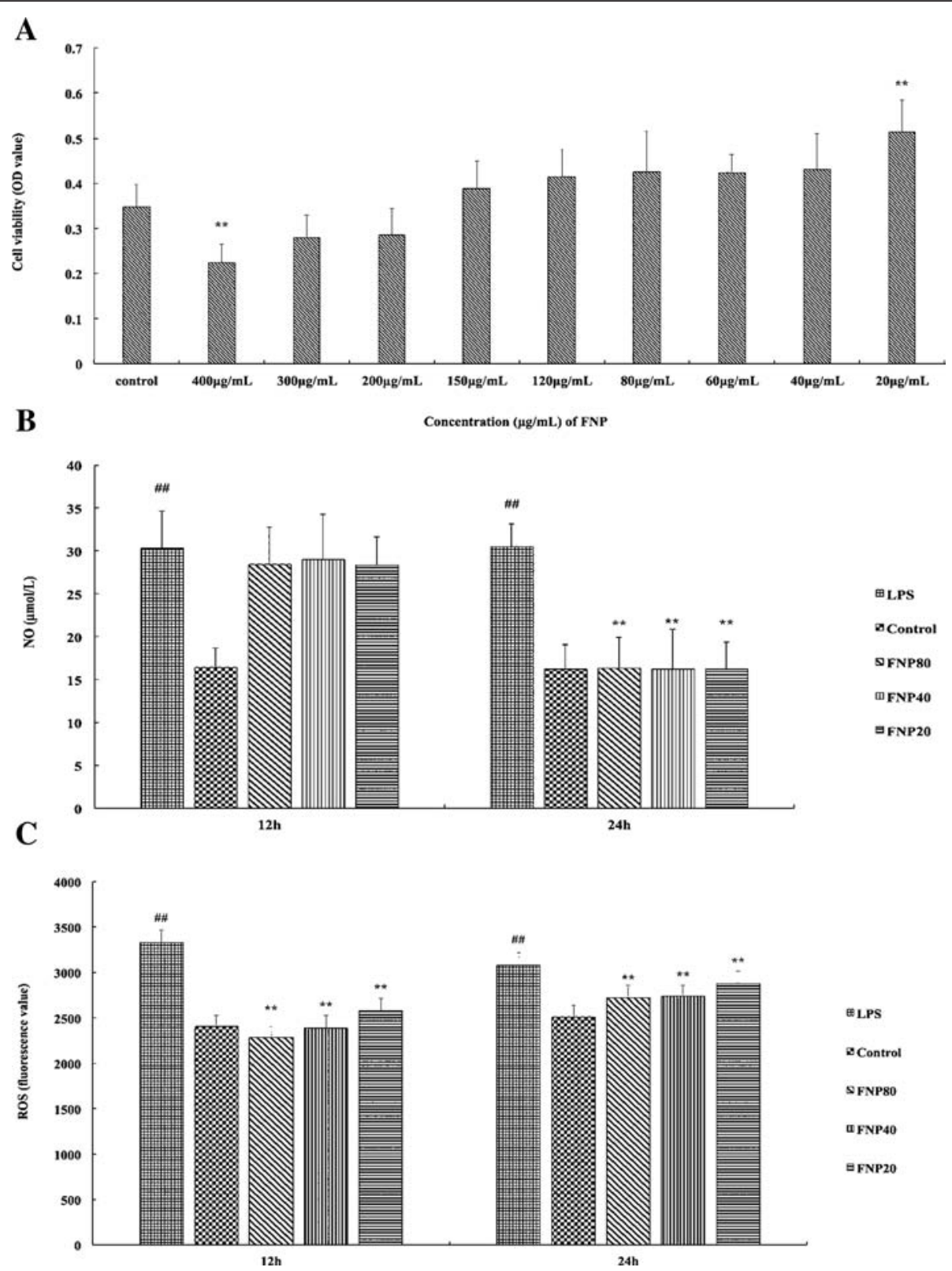

Fig. 5 Cytotoxic effects of FNP in RAW264.7 cells (a) and the effects of FNP on LPS-induced NO (b), and ROS (c) productions in RAW264.7 macrophages. Notes: The cells were incubated for $24 \mathrm{~h}$ with $1 \mathrm{~g} / \mathrm{mL}$ of LPS in the absence or presence of FNP (20, 40, and 80 g/mL). FNP was added $1 \mathrm{~h}$ before incubation with LPS. Cell viability assay was performed by using MTT assay. Nitrite concentration in the medium was determined by using Griess reagent. ROS production was determined by fluorescent probe DCFH-DA. Each column represented as the means \pm SD from three independent experiments. \#P $P 0.01$ vs control group; $* P<0.05$ vs LPS group; $* P<0.01$ vs LPS group

$\mathrm{mL}$ ) (Fig. $6 \mathrm{~b}$ ). The production of TNF- $\alpha$ and IL-1 $\beta$ was significantly inhibited as pretreated with FNP $(80$ and $40 \mu \mathrm{g} / \mathrm{mL}$ ) (Fig. 6a and 6b). Only pretreated by $80 \mu \mathrm{g} / \mathrm{mL}$ FNP significantly decreased production of IL-8 induced by LPS (Fig. 6b). FNP pretreatment showed no influence in production of IL-10 induced by LPS (Fig. 6b).

\section{Effects of FNP on iNOS and COX-2 protein expression in LPS-stimulated RAW 264.7 macrophages}

The expression levels of iNOS and COX-2 protein were examined by Western blot analysis using $\beta$-actin as an internal control. As shown in Fig. 7, RAW 264.7 cells with LPS treated alone resulted in significant increases in iNOS protein expressin, $4 \mathrm{~h}$ and $2 \mathrm{~h}$ FNP 

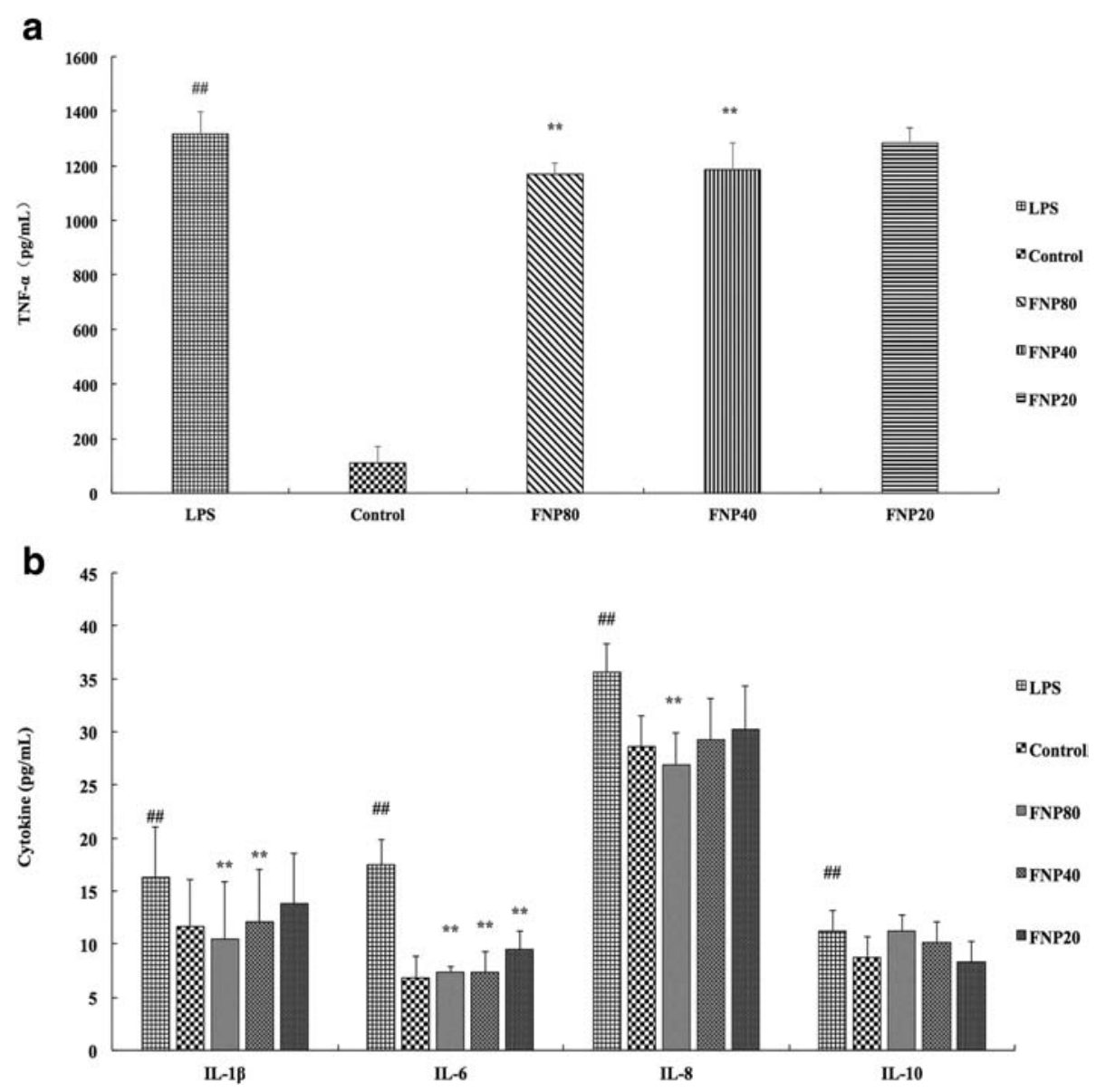

Fig. 6 Effects of FNP on LPS-induced TNF- $\alpha(\mathbf{a})$ and IL-6, IL-8, IL-10 and IL-1 $\beta$ (b) productions in RAW264.7 macrophages. Notes: The cells were incubated for $24 \mathrm{~h}$ with $1 \mathrm{~g} / \mathrm{mL}$ of LPS in the absence or presence of FNP $(20,40$, and $80 \mathrm{~g} / \mathrm{mL})$. FNP was added $1 \mathrm{~h}$ before incubation with LPS. Inflammatory cytokine level were determined by cytokine-specific ELISA kit. Each column represented as the means \pm SD from three independent experiments. \#P $P 0.01$ vs control group; $* P<0.05$ vs LPS group; $* *<<0.01$ vs LPS group

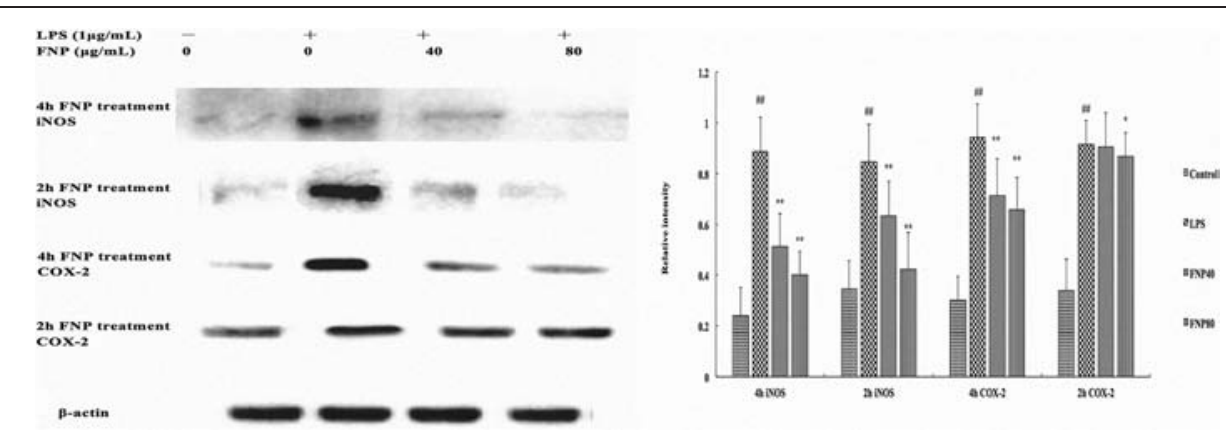

Fig. 7 Effects of FNP on iNOS and COX-2 protein expression in LPS-stimulated RAW264.7 cells. Notes: The cells were pretreated with different concentrations (40 g/mL, $80 \mathrm{~g} / \mathrm{mL}$ ) of FNP for $2 \mathrm{~h}$ or $4 \mathrm{~h}$ and stimulated with $1 \mathrm{~g} / \mathrm{mL}$ of LPS for $24 \mathrm{~h}$. Total cellular proteins (50 g) were separated by SDS-PAGE, then transferred to PVDF membrane and detected by Western blot analysis. Quantification of iNOS and COX-2 protein expression was normalized to $\beta$-actin using a densitometer. Each column represented as the means \pm SD from three independent experiments. $\# P<0.01$ vs control group; $* P<0.05$ vs LPS group; **P $<0.01$ vs LPS group 
pretreatment $(80 \mu \mathrm{g} / \mathrm{mL})$ significantly inhibited iNOS protein expression induced by LPS, the iNOS protein expression induced by LPS was decreased by $50.2 \%$ and $54.8 \%$ respectively. The expression levels of COX-2 protein were strongly induced by LPS, pretreated with FNP $(80 \mu \mathrm{g} / \mathrm{mL})$ for $4 \mathrm{~h}$ significantly inhibited COX-2 protein expression induced by LPS the protein expression induced by LPS was decreased by $30.0 \%$.

\section{Effects of FNP on LPS-induced MAPKs and AMPK phosphorylation in LPS-stimulated RAW 264.7 macrophages}

To investigate whether the inhibition of inflammatory mediator secretion by FNP is mediated through the MAPKs and AMPK pathway, we examined the effect of FNP on LPS-stimulated phosphorylation of ERK, JNK, p38 MAPKs,c-JUN and AMPK $\alpha$ in RAW 264.7 macrophages by Western blot analysis using phosphospecific antibodies. Cells were pretreated with different concentrationsof FNP for $2 \mathrm{~h}$ or $4 \mathrm{~h}$ and stimulated with $1 \mu \mathrm{g} / \mathrm{ml}$ of LPS for $1 \mathrm{~h}$. As shown in Fig. $8 \mathrm{~b}$ and $8 \mathrm{c}$, pretreated with FNP $(40 \mu \mathrm{g} / \mathrm{mL}$ and $80 \mu \mathrm{g} / \mathrm{mL}$ ) for $2 \mathrm{~h}$ and $4 \mathrm{~h}$ resulted in the notably inhibition of LPS-induced phosphorylation of ERK, JNK and c-JUN, whereas it did not affect p38 phosphorylation. As shown in Fig. 8c, RAW 264.7 cells with LPS treated alone resulted in significant decreased in the ratio of $\mathrm{p}-\mathrm{AMPK} \alpha / \mathrm{AMPK} \alpha$, pretreated with FNP for $2 \mathrm{~h}$ not affect the ratio of $\mathrm{p}-\mathrm{AMPK} \alpha / \mathrm{AMPK} \alpha$, whereas pretreated with FNP for $4 \mathrm{~h}$ notably increased it (Fig. 8b).

\section{Discussion}

Catechin, epicatechin, hyperin, isoquercitrin, isorhamnetin, kaempferol, quercetin, quercitrin, rhamnazin and rutin was found to contain in Various extracts and fractions of Polygonum hydropiper $L$. whole plant and herbs [30-32]. In this study, the content of flavonoids was determined by spectrophotometry using the aluminium chloride colorimetric method. Rutin was used as a reference standard and the flavonoid content express in $\mu \mathrm{g}$ rutin/mL of FNP. The principle of aluminum chloride colorimetric method is that aluminum chloride forms acid stable complexes with the C-4 keto group and either the C-3 or C-5 hydroxyl group of flavones and flavonols [33]. Only rutin, quercetin and quercitrin were used as standards in in the HPLC identification, so contents of rutin, quercetin and quercitrin $(50.7 \%)$ were less than total flavonoid content in FNP (55.3\%). According to our HPLC results in chromatographic condition of acetonitrile and $0.3 \%$ phosphoricacid (27:73, v/v), the contents of rutin, quercetin and quercitrin in FNP is $21.92 \%, 8.22 \%$ and $20.61 \%$ respectively, the retention times is $7.92 \mathrm{~min}, 26.53 \mathrm{~min}$ and $11.91 \mathrm{~min}$. According to the UPLC-MS identification in chromatographic condition of $19 \%$ methanol and $0.1 \%$ formic acid, the order of retention times of flavonoids in Polygonum hydropiper $L$. was found to be as follows: rutin $<$ hyperin $<$
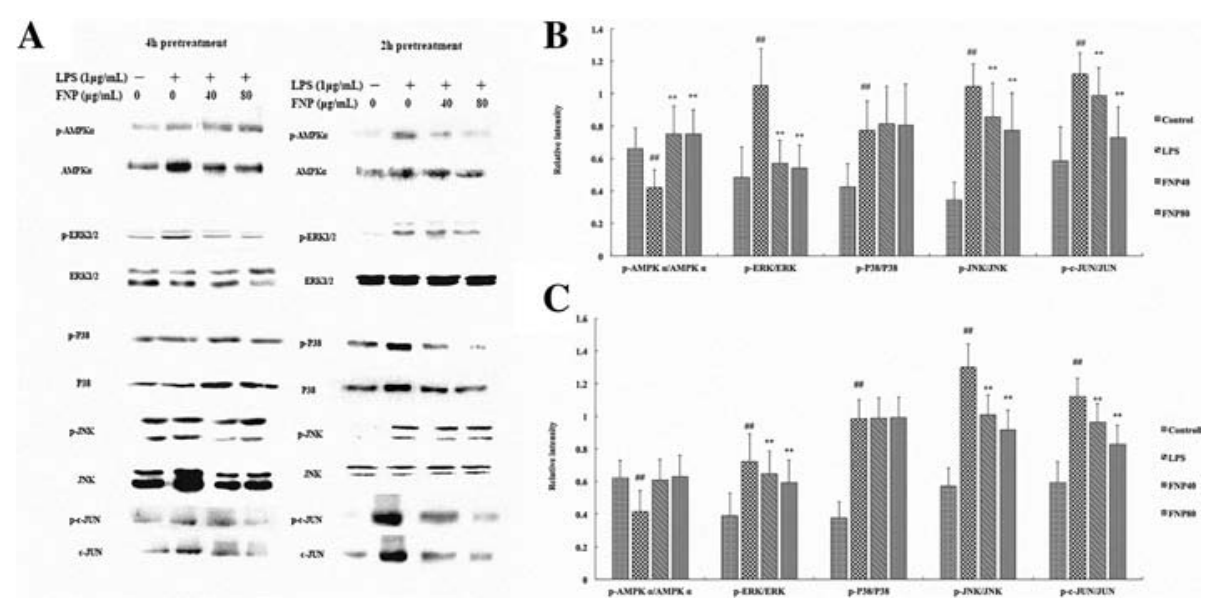

Fig. 8 Effects of FNP on phosphorylation of MAPKs and AMPK in LPS-stimulated RAW264.7 cells. Notes: The cells were pretreated with different concentrations (40 g/mL and $80 \mathrm{~g} / \mathrm{mL}$ ) of FNP for $2 \mathrm{~h}$ or $4 \mathrm{~h}$ and stimulated with $1 \mathrm{~g} / \mathrm{ml}$ of LPS for $1 \mathrm{~h}$. Total cellular proteins (50 g) were separated by SDS-PAGE, then transferred to PVDF membrane and detected by Western blot analysis. Western blot results were shown in (a). Quantification of p-AMPKa, p-ERK1/2, p-P38, p-JNK and p-c-JUN protein expression was normalized to AMPKa, ERK1/2, P38, JNK and c-JUN using a densitometer. Each column represented as the means \pm SD from three independent experiments. Results of 4 h pretreatment were shown in (b) and results of $2 \mathrm{~h}$ pretreatment were shown in (c). \#P<0.05 vs control group; \# $P<0.01$ vs control group; $* P<0.05$ vs LPS group; **P $<0.01$ vs LPS group 
isoquercitrin $<$ quercitrin $<$ catechin $<$ epicatechin $<$ quercetin $<$ kaempferol $<$ isorhamnetin [31]. We speculated FNP contain catechin and epicatechin.

Intraperitoneal injectetion of LPS has been used as a common experimental inflammation model and characterized by increased levels of neutrophils, protein content, inflammatory cytokines, chemokines and lung injury $[26,34]$. In the present study, as expected, mice stimulated with LPS exhibited a high mortality. Pretreatment with FNP markedly reduced the mortalities indicated that FNP could significantly protect mice from LPS-induced death. Proinflammatory cytokines including TNF- $\alpha$ and IFN- $\gamma$, which playing a prominent role in the pathogenesis of tissue injury evolving from septic shock, are contributing to the protection of the lung against severe damage [35]. In a Gram-positive sepsis modle, mRNA expression levels of TNF- $\alpha$ and IFN- $\gamma$ significantly increase [36]. Next, we investigated the inhibitory effect of FNP on histological alterations and mRNA expression levels of proinflammatory cytokines in lung. In our study,FNP pretreatment dramatic decreased the mRNA expression of TNF- $\alpha$, IFN- $\alpha$, IFN- $\gamma$ and IL- 2 induced by LPS in lung, attenuated lung injury by decreasing alveolar incrassation and PMN infiltration. These results showed that FNP exert a salutary effect on acute lung injury in LPS-stimulated mice. Reactive oxygen species have been found to have a role in the pathogenesis of LPS-induced gastrointestinal motility disturbances [37]. LPS injection increases the levels of oxidative damage in plasma and intestine [38]. We investigated the inhibitory effect of FNP on MDA and MPO levels in small intestine homogenates, histological alterations in ileum and colon. Our results suggested that FNP pretreatment attenuated ileum and colon injuries by decreasing MDA and MPO levels, these results showed that FNP exert a salutary effect on intestinal damage in LPS-stimulated mice. Thus, we can draw a conclusion that FNP exerted benefits on lung and intestinal injury in LPS-stimulated mice.

The pathogenesis of sepsis involves disorders of oxidant/ anti-oxidant and inflammation/anti-inflammation, and the increased production of inflammatory cytokines. ROS, NO and the potent proinflammatory cytokines (such as TNF- $\alpha$, IL-1 $\beta$ and IL-6) play an important role in the occurrence and development of systemic inflammatory responses $[39,40]$. Flavonoid compound derived from natural plant inhibits the activation of macrophage and protects mice from macrophage-mediated endotoxin shock [41]. In the present study, the results of in vivo experiment showed that FNP pretreatment suppressed LPS-induced TNF- $\alpha$ production in serum, liver and small intestine. In addition, the results of in vitro experiment showed that FNP pretreatment suppressed LPS-induced inflammatory cytokines (TNF- $\alpha$, IL-
1 $\beta$, IL-6、IL-8), NO and ROS production in RAW 264.7 cells. Considering a critical role of ROS, NO and inflammatory cytokines in septic shock, increased survival of mice and reduction of multiple organ injury might be mediated by inhibition the production of ROS, NO and inflammatory cytokines in activated macrophage.

To alleviate cumulative burden of oxidative stress, cells generally utilize anti-oxidant defense systems to scavenge ROS. SOD and GSH-PX are the first line of defense against oxidative stress and can inhibit free radical formation and prevent oxidative damage by ROS [42]. In this paper, to determine whether the protective effects of FNP on multiple organ injury in LPSstimulated mice were mediated by their antioxidant functions, the activities of antioxidant enzymes in mice under sepsis with or without pretreatment of FNP were investigated. In the present study, the results of in vivo experiment showed that FNP pretreatment significantly promoted T-AOC, T-SOD, GSH-PX and GSH levels as compared to LPS group, suggesting that FNP pretreatment significantly attenuated the oxidative damage of LPS-stimulated mice by maintaining the activity of antioxidant enzymes.

Over production of $\mathrm{NO}$ and $\mathrm{PGE}_{2}$ was due to overexpression of iNOS and COX-2. During infection, inflammation injury was caused by uncontrolled release of NO, while $\mathrm{PGE}_{2}$ was contributed to edema, angiogenesis and invasion [43]. To explore possible mechanism of antiinflammatory effect by FNP pretreatment, we study its effects on iNOS and COX-2 protein expression in LPSstimulated RAW264.7 cells. In the present study, our results showed that FNP pretreatment significantly attenuated the LPS-induced up-regulation of iNOS, COX-2 protein expressions in RAW264.7 macrophages, indicating that the inhibition of $\mathrm{NO}$ and PGE2 production by FNP is a result of the inhibition of iNOS and COX-2 protein expressions. AMPK activation suppressed the LPS-induced expression of pro-inflammatory cytokines in glial cells [44], vascular endothelial cells [45] and BV-2 microglia cells [46]. However, AMPK activation promoted inflammatory cytokines production in in cardiac fibroblasts of adult mice [47] or human synovial fibroblast cells [48]. To verify the role of AMPK $\alpha$ in macrophage, we investigated the phosphorylation of $\mathrm{p}$ AMPK $\alpha /$ AMPK $\alpha$ in LPS-induced RAW264.7 cells and observed a decrease in ratio of $\mathrm{p}-\mathrm{AMPK} \alpha / \mathrm{AMPK} \alpha$. FNP pretreatment increase ratio of $\mathrm{p}-\mathrm{AMPK} \alpha / \mathrm{AMPK} \alpha$, suggesting that the anti-inflammatory activity of FNP was partly regulated by AMPK $\alpha 1$ subunit.

ERK, JNK and p38, the activation and phosphorylation of these three subtypes MAPKs play certain roles in anti-inflammatory mechanism in LPS-induced macrophages [49]. Evidence were shown that p38 and ERK are involved in iNOS production in LPS-induced RAW264.7 
cells [50], while another study showed that p38 and ERK activation up-regulates LPS-induced COX-2 expression in RAW264.7 cells [51]. In the present study, our results observed that FNP pretreatment significantly inhibited the phosphorylation/activation of JNK and ERK in LPSinduced RAW264.7 macrophages, while extended pretreatment to $4 \mathrm{~h}$, stronger inhibiting effect in these subtypes MAPKs were shown. These results suggesting suppression of FNP pretreatment on inflammatory mediators may be regulated by the ERK and JNK MAPKs signaling pathways. Moreover, activated JNK induced phosphorylation of c-JUN in ser73 and ser63. Our results indicated that FNP pretreatment suppressed phosphorylation/activation of c-JUN induced by LPS. Thus, we can draw a conclusion that anti-inflammatory activities of FNP may be mediated by inhibiting the phosphorylation of JNK, ERK and c-JUN in MAPKs signaling pathways.

\section{Conclusions}

Our present study demonstrated that FNP isolated from Polygonum hydropiper $L$. possesses antioxidant and antiinflammatory activities. The anti-inflammatory mechanism of FNP might be related to the decrement of the level of MDA, MPO and ACP via increasing the activities of T-AOC, T-SOD, GSH-PX and GSH. FNP inhibited iNOS and COX-2 protein expression in LPSstimulated RAW264.7 macrophages. The inhibitory effects of FNP may be mediated by suppression of JNK, ERK MAPKs signaling pathways.

\section{Abbreviations \\ ACP: Acid phosphatase; AMPK: AMP-activated protein kinase; BSA: Bovine serum albumin; COX-2: Cyclooxygenase-2; CT value: Cycle threshold; DCFH- DA: Dichlorofluorescin diacetate; DMEM: Dulbecco minimum essential medium; DMSO: Dimethyl Sulphoxide; ECL: Enhanced chemiluminescence; ELISA: Enzyme-linked immuno sorbent assay; ERK: Extracellular signal regulated kinase; FNP: Flavonoids from normal butanol fraction of Polygonum hydropiper L. extract; GSH: Glutathione; GSH-PX: Glutathione peroxidase; HPLC: High Performance Liquid Chromatography; IFN-a: Interferon-a; IFN-

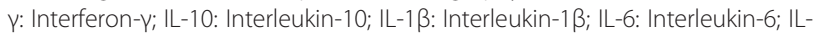 8: Interleukin-8; iNOS: inducible nitric oxide synthase; JNK: c-Jun N terminal kinase; LPS: Lipopolysaccharide; LZM: Lysozyme; MAPKs: Mitogen-activated protein kinases; MDA: Malondialdehyde; MPO: Myeloperoxidase; mRNA: messenger RNA; MTT: 3-(4, 5-Dimethylthiazol-2-yl)-2, 5- diphenyltetrazolium bromide; NO: Nitric oxide; NOS: Nitric oxide synthase; PBS: Phosphate-buffered saline; PGC-1a: Peroxisome proliferator-activated receptor- $\gamma$ coactivator 1 a; PGE2: Prostaglandin E2; PMN: Polymorphonuclear neutrophil; RNS: Reactive nitrogen species; ROS: Reactive oxygen species; T- AOC: Total antioxidant capacity; TNF-a: Tumor necrosis factor-a; T-SOD: Total superoxidase dismutase; TTBS: Tween 20/ Tris buffered saline.}

\section{Competing interests}

The authors declare that there is no conflict of interests regarding the publication of this paper.

\section{Authors' contributions}

TJH participated in the design of the study, JYT carried out the extract of plant, the antioxidant activity studies and the western blot assay. YYW carried out the histopathological sections and cell culture. JYT carried out the date analysis and wrote the manuscript. All authors read and approved the final manuscript.

\section{Acknowledgments}

This work was financially supported by the National Natural Science Foundation of China (No.31560708) and Science Foundation of Guangxi University (XBZ120918).

Received: 9 September 2015 Accepted: 12 January 2016

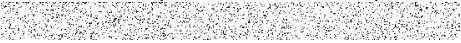

\section{References}

1. Bone RC, Grodzin CJ, Balk RA. Sepsis: a new hypothesis for pathogenesis of the disease process. CHEST J. 1997;112(1):235-43.

2. Danai P, Martin GS. Epidemiology of sepsis: recent advances. Curr Infect Dis Rep. 2005;7(5):329-34.

3. Cribbs SK, Martin GS. Expanding the global epidemiology of sepsis. Crit Care Med. 2007:35(11):2646-8.

4. Angus DC, Linde-Zwirble WT, Lidicker J, Clermont G, Carcillo J, Pinsky MR. Epidemiology of severe sepsis in the United States: analysis of incidence, outcome, and associated costs of care. Crit Care Med. 2001;29(7):1303-10.

5. Saltzberg JMR. Fever and signs of shock: the essential dangerous fever. Emerg Med Clin North Am. 2013;31(4):907-26.

6. Lagu T, Rothberg MB, Shieh MS, Pekow PS, Steingrub JS, Lindenauer PK. What is the best method for estimating the burden of severe sepsis in the United States? J Crit Care. 2012;27(4):e411-419.

7. Wolk DM, Fiorello AB. Code sepsis: rapid methods to diagnose sepsis and detect hematopathogens. Clin Microbiol Newslet. 2010;32(5):37.

8. Alqahtani MF, Marsillio LE, Rozenfeld RA. A review of biomarkers and physiomarkers in pediatric sepsis. Clin Pediatr Emerg Med. 2014;15(2):177-84.

9. Sharawy N, Pavlovic D, Wendt M, Cerny V, Lehmann C. Evaluation of the effects of gender and estradiol treatment on the intestinal microcirculation during experimental sepsis. Microvasc Res. 2011;82(3):397-403.

10. Lowes DA, Thottakam BM, Webster NR, Murphy MP, Galley HF. The mitochondria-targeted antioxidant MitoQ protects against organ damage in a lipopolysaccharide-peptidoglycan model of sepsis. Free Radic Biol Med. 2008:45(11):1559-65.

11. Sharma R, Tepas 3rd JJ, Hudak ML, Mollitt DL, Wludyka PS, Teng RJ, et al. Neonatal gut barrier and multiple organ failure: role of endotoxin and proinflammatory cytokines in sepsis and necrotizing enterocolitis. J Pediatr Surg. 2007;42(3):454-61.

12. Moreillon P, Majcherczyk P. Proinflammatory activity of cell-wall constituents from gram-positive bacteria. Scand J Infect Dis. 2003;35(9):632-41.

13. Ritter C, Andrades ME, Reinke A, Menna-Barreto S, Moreira JC, Dal-Pizzol F. Treatment with $\mathrm{N}$-acetylcysteine plus deferoxamine protects rats against oxidative stress and improves survival in sepsis*. Crit Care Med. 2004;32(2): 342-9.

14. Vassilev D, Hauser B, Bracht $H$, Iványi Z, Schoaff M, Asfar P, et al. Systemic, pulmonary, and hepatosplanchnic effects of $\mathrm{N}$-acetylcysteine during longterm porcine endotoxemia. Crit Care Med. 2004;32(2):525-32.

15. Merve B, Sevtap AN, Gökta HG, ahin T, Ba aran AA, et al. The protective role of ferulic acid on sepsis-induced oxidative damage in wistar albino rats. Environ Toxicol Pharmacol. 2014;38(3):774-82.

16. Kim AR, Lee MS, Shin TS, Hua H, Jang BC, Choi JS, et al. Phlorofucofuroeckol $A$ inhibits the LPS-stimulated iNOS and COX-2 expressions in macrophages via inhibition of NF-kappaB, Akt, and p38 MAPK. Toxicol In Vitro. 2011;25(8): 1789-95.

17. Lin YC. Anti-inflammatory actions of Syk inhibitors in macrophages involve non-specific inhibition of toll-like receptors-mediated JNK signaling pathway. Mol Immunol. 2010;47(7-8):1569-78.

18. Guimarães MR, Leite FR, Spolidorio LC, Kirkwood KL, Rossa Jr C. Curcumin abrogates LPS-induced pro-inflammatory cytokines in RAW 264.7 macrophages. Evidence for novel mechanisms involving SOCS-1, -3 and p38 MAPK. Arch Oral Biol. 2013;58(10):1309-17.

19. Park HH, Mi JK, Ying L, Park YN, Lee J, Lee YJ, et al. Britanin suppresses LPSinduced nitric oxide, PGE2 and cytokine production via NF- B and MAPK inactivation in RAW 264.7 cells. Int Immunopharmacol. 2013;15(2):296-302.

20. Zhang T-T, Wang M, Yang L, Jiang J-G, Zhao J-W, Zhu W. Flavonoid glycosides from Rubus chingii Hu fruits display anti-inflammatory activity through suppressing MAPKs activation in macrophages. J Funct Foods. 2015;18:235-43.

21. Wang W, Zhang Y, Xu M, Zhang Y-Y, He B. Fenoterol inhibits LPS-induced AMPK activation and inflammatory cytokine production through $\beta$-arrestin-2 in THP-1 cell line. Biochem Biophys Res Commun. 2015;462(2):119-23. 
22. Yagi A, Uemura T, Okamura N, Haraguchi H, Imoto T, Hashimoto K. Antioxidative sulphated flavonoids in leaves of Polygonum hydropiper. Phytochemistry. 1994;35:885-7.

23. Haraguchi $\mathrm{H}$, Hashimoto $\mathrm{K}$, Yagi A. Antioxidative substances in leaves of Polygonum hydropiper. J Agric Food Chem. 2002;40(8):1349-51.

24. Yang $Y, Y u T$, Jang HJ, Byeon SE, Song SY, Lee BH, et al. In vitro and in vivo anti-inflammatory activities of Polygonum hydropiper methanol extract. J Ethnopharmacol. 2012;139(2):616-25.

25. Jin SL, Yin YG. In vivo antioxidant activity of total flavonoids from indocalamus leaves in aging mice caused by D-galactose. Food Chem Toxicol. 2012;50(10):3814-8

26. Tong Q, Zheng L, Kang Q, Dodd OJ, Langer J, Li B, et al. Upregulation of hypoxia-induced mitogenic factor in bacterial lipopolysaccharide-induced acute lung injury. FEBS Lett. 2006;580(9):2207-15.

27. Pathak N, Khandelwal S. Role of oxidative stress and apoptosis in cadmium induced thymic atrophy and splenomegaly in mice. Toxicol Lett. 2007; 169(2):95-108.

28. Green LC, Wagner DA, Glogowski J, Skipper PL, Wishnok JS, Tannenbaum SR. Analysis of nitrate, nitrite, and [15 N] nitrate in biological fluids. Anal Biochem. 1982;126(1):131-8.

29. Wu J, Jing L, Yuan H, Peng S-q. T-2 toxin induces apoptosis in ovarian granulosa cells of rats through reactive oxygen species-mediated mitochondrial pathway. Toxicol Lett. 2011;202(3):168-77.

30. Yusif KS, Blinova KF. Flavonoid aglycones of Polygonum hydropiper. Chem Nat Compd. 1984;20(5):625-6.

31. Yang X, Wang BC, Zhang X, Yang SP, Li W, Tang Q, et al. Simultaneous determination of nine flavonoids in Polygonum hydropiper $L$. samples using nanomagnetic powder three-phase hollow fibre-based liquid-phase microextraction combined with ultrahigh performance liquid chromatography-mass spectrometry. J Pharm Biomed Anal. 2011;54(2):311-6.

32. Hawrył MA, Waksmundzka-Hajnos M. Two-dimensional thin-layer chromatography of selected Polygonum sp. extracts on polar-bonded stationary phases. J Chromatogr A. 2011;1218(19):2812-9.

33. Hassan S, Al Aqil A, Attimarad M. Determination of crude saponin and total flavonoids content in guar meal. Adv Med Plant Res. 2013;1(2):24-8.

34. Soromou LW, Chu X, Jiang L, Wei M, Huo M, Chen N, et al. In vitro and in vivo protection provided by pinocembrin against lipopolysaccharideinduced inflammatory responses. Int Immunopharmacol. 2012;14(1):66-74.

35. Yamaguchi T, Hirakata Y, Izumikawa K, Miyazaki Y, Maesaki S, Tomono K, et al. Prolonged survival of mice with Pseudomonas aeruginosa-induced sepsis by rIL-12 modulation of IL-10 and interferon- $\gamma$. J Med Microbiol. 2000; 49(8):701-7.

36. Vallespi MG, Colas M, Garay H, Reyes O, Arana MJ. Differential regulation of Th1/Th2 in relevant tissues for sepsis pathogenesis with a Limulus anti-LPS factor-derived peptide increases survival in Gram-positive sepsis. Int Immunopharmacol. 2004;4(10-11):1343-51.

37. de Winter BY, van Nassauw L, de Man JG, de Jonge F, Bredenoord AJ, Seerden TC. Role of oxidative stress in the pathogenesis of septic ileus in mice. Neurogastroenterol Motil. 2005;17(2):251-61.

38. Gonzalo S, Grasa L, Arruebo MP, Plaza MA, Murillo MD. Inhibition of p38 MAPK improves intestinal disturbances and oxidative stress induced in a rabbit endotoxemia model. Neurogastroenterol Motil. 2010;22(5):564-72.

39. Xq W, Charles IG, Smith A, Ure J, Feng G-j, Huang F-p, et al. Altered immune responses in mice lacking inducible nitric oxide synthase. 1995.

40. Schwabe RF, Brenner DA. Mechanisms of liver injury. I. TNF-a-induced liver injury: role of IKK, JNK, and ROS pathways. Am J Physiol-Gastr L. 2006;290(4): G583-9.

41. Liu LL, Gong LK, Wang H, Xiao Y, Wu XF, Zhang YH, et al. Baicalin inhibits macrophage activation by lipopolysaccharide and protects mice from endotoxin shock. Biochem Pharmacol. 2008;75(4):914-22.

42. Liu J, Liang J, Kan J, Jin CH. In vitro and in vivo antioxidant activity of ethanolic extract of white button mushroom (Agaricus bisporus). Food Chem Toxicol. 2013;51:310-6.

43. Murakami A, Ohigashi H. Targeting NOX, iNOS and COX-2 in inflammatory cells: Chemoprevention using food phytochemicals. Int J Cancer. 2007; 121(11):2357-63.

44. Giri S, Nath N, Smith B, Viollet B, Singh AK, Singh I. 5-aminoimidazole-4carboxamide-1-beta-4-ribofuranoside inhibits proinflammatory response in glial cells: a possible role of AMP-activated protein kinase. J Neurosci. 2004 24(2):479-87.
45. Yoshiyuki H, Yasuko N, Sachiko H, Atsuko T, Kouichi I, Kiuo K. High molecular weight adiponectin activates AMPK and suppresses cytokine-induced NFkappaB activation in vascular endothelial cells. FEBS Lett. 2008;582(12):1719-24.

46. Dah-Yuu L, Chih-Hsin T, Yi-Hung C, I-Hua W. Berberine suppresses neuroinflammatory responses through AMP-activated protein kinase activation in BV-2 microglia. J Cell Biochem. 2010;110(3):697-705.

47. Du JH, Xu N, Song Y, Xu M, Lu ZZ, Han C, et al. AlCAR stimulates IL-6 production via p38 MAPK in cardiac fibroblasts in adult mice: a possible role for AMPK. Biochem Biophys Res Commun. 2005;337(4):1139-44.

48. Chih-Hsin T, Yung-Cheng C, Tzu-Wei T, Rong-Sen Y, Wen-Mei F. Adiponectin enhances IL-6 production in human synovial fibroblast via an AdipoR1 receptor, AMPK, p38, and NF-kappa B pathway. J Immunol. 2007;179(8): 5483-92.

49. Kaminska B. MAPK signalling pathways as molecular targets for antiinflammatory therapy-from molecular mechanisms to therapeutic benefits. Biochim Biophys Acta. 2005;1754(1-2):253-62.

50. Ajizian SJ. Specific inhibitors of p38 and extracellular signal-regulated kinase mitogen-activated protein kinase pathways block inducible nitric oxide synthase and tumor necrosis factor accumulation in murine macrophages stimulated with lipopolysaccharide and interferon-gamma. J Infect Dis. 1999, 179(4):939-44.

51. Paul A. Involvement of mitogen-activated protein kinase homologues in the regulation of lipopolysaccharide-mediated induction of cyclo-oxygenase-2 but not nitric oxide synthase in RAW 264.7 macrophages. Cell Signal. 1999; $11: 491-7$

\section{Submit your next manuscript to BioMed Central and we will help you at every step:}

- We accept pre-submission inquiries

- Our selector tool helps you to find the most relevant journal

- We provide round the clock customer support

- Convenient online submission

- Thorough peer review

- Inclusion in PubMed and all major indexing services

- Maximum visibility for your research

Submit your manuscript at www.biomedcentral.com/submit

) Biomed Central 